\title{
ПРИСЪСТВИЕТО НА ДРИНОВСКИЯ ПРАВОПИС В БЪЛГАРСКИЯ КНИЖОВЕН ЕЗИК (1870-1944)
}

\author{
Р. Камберова, М.-Й. Василева
}

\begin{abstract}
Камберова Р., Василева М.-Й. Присъствието на Дриновския правопис в българския книжовен език (1870-1944). Статията има за цел да представи приноса на Марин Дринов към развитието на съвременния български книжовен език. С тази цел се проследява как Дриновският правопис става основа на останалите правописи. Периодът, който се разглежда обхваща времето от Възраждането до 1945 година.
\end{abstract}

Ключови думи: правопис; Дринов; буква; думи; език; норма.

Камберова Р., Василева М.-Й. Присутствие Дриновской орфографии в болгарском литературном языке (1870-1944). В статье проанализирован вклад Марина Дринова в развитие современного болгарского литературного языка. С этой целью представлена орфография Дринова как основа других орфографий. Рассматриваемый период охватывает время от эпохи Возрождения до 1945 года.

Ключевые слова: орфография; Дринов; буква; слово; язык; кодификация.

Kamberova R., Vasileva M.-Y. The Presence of Drinov's Orthography in Bulgarian Standard Language (1870-1944). The article aims to present the contribution of Marin Drinov's orthography to the Modern Bulgarian standard language. For this prurpose it follows the process of the Drinov's orthography becoming a base for the next codification. The considered period covers the time from the Bulgarian Renaissance to 1945.

Keywords: orthography; Drinov; letter; word; language; codification.

Всяка система, за да се развива и функционира, има нужда от норми и правила. Езикът не прави изключение и неговите правила обикновено биват описани в единна правописна система, приета и позната на тези, които го използват. С течение на времето и естественото развитие на езика правописната система може и е желателно да се променя, за да отразява състоянието на езика.

В годините преди Освобождението в българската възрожденска общност се зараждат идеи за кодификация на книжовния език. Този процес е логичен и е обоснован от пробуждането на националното самосъзнание и засилването на книжовната дейност. В този период се появяват редица нови вестници и списания, излиза първият речник, публикуват се сборници със събрани фолклорни текстове и други, което кара българските възрожденци да се интересуват по-активно от правописните правила и в крайна сметка да започнат да публикуват своите виждания по въпроса. Разбираемо е, че техните становища и предложения намират отражение най-вече в бурно развиващия се тогава периодичен печат. Той е достъпна трибуна за новите идеи, предоставя широк достъп до информацията и бърза връзка с обществото. От това се възползва и Петко Р. Славейков, който през 1863 г. започва да издава вестник „Гайда“. В него българският възрожденец предлага правописни правила, според които следва да се пише без краесловните ерове. Това е първият опит за промяна, който не отговаря обаче на тогавашното състояние на говоримия език ${ }^{1}$.

Няколко години по-късно Любен Каравелов започва да издава вестник „Свобода“ в Букурещ. Той стига по-далеч от Славейков като публикува във вестника кратка статия, посветена на правописа - „За езикът“ (в бр. 16). В нея Л. Каравелов представя своите виждания по въпроса за правописа на българския език и прави предложението да се пише това, което се чува. „Трябва да пишем с толкова букви, с колкото е потребно; нито с повече, нито с по-малко. За един звук не трябва да пишем три гласни букви, защото туй не само че не докарва никаква полза за езика, а плаши децата с непотребни мъчнотии““2. Правописното предложение на Л. Каравелов е възприето от Христо Ботев и дори за известно време е широко използвано от емигрантския печат в Букурещ³. 
Пред зараждащата се българска нова интелигенция стоят множество въпроси за решаване. Нашите възрожденци си дават ясна сметка, че за успешното развитие на книжовния език са необходими освен политически и културен център, независимост и държавна структура, но също така и научна институция, което компетентно да се занимава с въпросите на езика и историята. Така през 1869 г. в Браила е основано Българското книжовно дружество, което дава по-късно основата на Българската академия на науките. Един от учредителите на дружеството и пръв негов председател е видният историк Марин Дринов - учен с широк спектър на интереси, достигнал забележителни върхове в областта на историята, литературознанието, етнографията, езикознанието. Историк по основно свое занимание, Марин Дринов разбира, че проучванията в областта на езика, литературата, фолклора трябва да вървят паралелно, за да бъдат обективни. В тази връзка той се спира и на въпроса за правописа, именно защото познава историята на книжовния език и осъзнава каква е силата и необходимостта от точно и ясно формулирана езикова норма.

Година след създаването на Българското книжовно дружество започва издаването на сп. „Периодическо списание““. В него М. Дринов публикува статията си „За новобългарското азбуке“. Правописът, чиито основи залага в нея, не след дълго започва да се употребява от широката общественост и за него започва да се говори като за Дриновски правопис. От неговите правила започват да се ръководят официални списания, той играе значителна роля след Освобождението и съдържа редица положения, които са влезли в нашата съвременна правописна система 4 .

Основната цел на Марин Дринов при създаването на правописната норма е тя да бъде функционална и достьпна. В основата ѝ стоят два принципа - опирането на живата българска реч с всичките $\mathrm{J}$ диалектни видоизменения и комбинирането ѝ със стария български език. Ученият осъзнава, че приемането на общ правопис няма да е лесен и еднороден процес, тъй като за това се иска „сговорьт поне на по-пьрвите ни писатели, понеже „у нас твърде малко е позната науката за езикът, язиковедението“"5.

Марин Дринов дълго обмисля правописните въпроси и ги разисква със своите съвременници и съмишленици писатели като Нешо Бончев, Райко Жинзифов, Петко Каравелов. Ученият смята, че за съставянето на обща писмена норма трябва да се приеме единна норма в съответствие с духа и свойствата на езика и да се приемат еднакви думи, еднакъв строй на речта ${ }^{6}$.

Освен „Писмо до българските читалища“ (1869) особено значима в нормативно отношение е статията на Марин Дринов „За новобългарското азбуке“ (1870), където е представена цялостна програма за изучаването на езика и историята на българите. Може би по-важното е, че той залага като основен научния подход към решаването на въпросите, които възникват. Така например е известно, че сред някои от съвременниците му (Н. Рилски, Р. Жинзифов, К. Шапкарев и др.) се шири схващането, че е добре да се смесват говорни особености от различни области, което те правят в творчеството си съзнателно. Марин Дринов обаче не приема подобен подход и изразява мнение, че това е изкуствено сглобяване на писмен език 7 . Принципната му позиция по този въпрос е отразена в статиите, които публикува.

В поредица от статии Марин Дринов предлага и защитава правописни правила, но като дата на „раждането“ на правописа се смята годината 1870.

Главните особености на Дриновския правопис (а и на тези след това) са подробно описани от известния езиковед Любомир Андрейчин ${ }^{8}$ :

a) $\boldsymbol{b}$-изговор (правописно $\mathbf{2}$ ) на глаголните окончания за 1 л. ед. ч. и 3 л. мн. ч. в сегашно време (четл, четк $m$ );

б) предпочитание към твърди окончания във II спрежение;

в) подвижна гласна в в случаи като върба - Връбница, гълча - гльчка;

г) окончание -и при многосрични съществителни от мъжки род (българи, орачи);

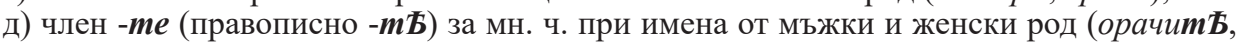
книгить);

е) член -ий при прилагателните от мъжки род (малкий, голБмий);

ж) енклитични местоименни форми ме, $\boldsymbol{m e}, \boldsymbol{c e}$.

Дриновският правопис официално действа до 1892 г., когато министърьт на народната просвета Георги Живков назначава комисия за решаване на правописния въпрос. В нея 
участват преподавателите от Софийския университет Любомир Милетич, Александър Теодоров-Балан, Беньо Цонев, Иван Шишманов, Д. Матов, Ст. Аргиров и др. Не след дълго комисията публикува правописен проект в новооснованото списание „Български преглед“ (септември 1893 г.). В същия брой излиза статията на Л. Милетич „Нашата правописна реформа“. Според него следва да отпаднат краесловните ерове, да се замени $\boldsymbol{\mathbf { s }} \mathbf{c} \mathbf{b}$, да се премахнат юсовете в глаголните окончания, да се установят меките окончания в глаголи като нося - носят, капя - капят, да се замени ятовата гласна с $я$ и $e$; да се уеднакви правописът на звучните сьгласни при представките на -з, да се отстрани членната форма на -ий при прилагателните (добрият, добрия, а не добрий), да се премахнат двойните съгласни в чужди думи 9 .

Предложеният от комисията проект съвпада в някои отношения с Дриновския правопис. Така например ятовата гласна се запазва само със стойност на $я$, тоест остава да се пише само там, където се изговаря в книжовното произношение като я (вБра, голБм, иЂл), а се заменя с $e$ в случаите, когато се преглася в $e$ (големи, големина, целият, цели) (пак там).

Правописът е прилаган пробно в първите четири книжки на сп. „Български преглед“, след което редакцията на списанието се връща към Дриновския правопис, предоставяйки на авторите сами да решат към кой правопис да се придържат при печата на своите трудове ${ }^{10}$.

През 1895 г. новият министьр на просветата Константин Величков назначава друга комисия - подкомисия. Този пьт в нея освен членовете от предната такава са включени и техните идейни противници - Иван Вазов, Стоян Михайловски, Тодор Влайков, д-р Кръстьо Кръстев, Ив. Шишманов, Ив. Пеев-Плачков и др. Комисията изработва проект за правопис, сьгласно който $\breve{u}, я, ю$ се запазват, ж се замества с $ъ$ в корените на думите (дъб, ръка, късам), ж и $t \kappa$ с $a$, я в глаголните окончания (чета - чет $a$ т, нося - носят); Б се замества с $я$ и $e$, връща се употребата на $b$ и $b$ в края на думите, пълният член при имената от мъжки род се употребява в именителен падеж, а краткият - в косвен падеж ${ }^{11}$. Опитите този проект да бъде въведен остават безуспешни, освен в сп. „Български преглед“, и на практика отново се употребява главно Дриновският правопис.

През 1898 г. поста министьр на просветата заема Иван Вазов, който, без да назначава отново комисия, отпечатва „Упътване за общо правописание“. Според изтъкнатия езиковед Р. Русинов в „История на българския правопис“ не е ясно чие дело е този текст, тъй като на него няма никакво съобщение кой е авторьт или авторите и с участието на кой орган е издадено то ${ }^{12}$. Този правопис отново се заврьща към традиционния правопис с етимологичното писане на $\bar{b}, \ldots, b$, с ж и $九$ в глаголните окончания, с краесловните ерове, врьща окончанието на -не, а не -нье при отглаголните съществителни (ходене, писане, а не ходенье, писанье). Всьщност упътванията на Иван Вазов не се разграничават много от правилата на Дриновския правопис. Нововъведенията се състоят в приема при имената от мъжки род на пълна и кратка членна форма (-ъm, -bm, -яm и - $a,-я)$, разграничавани по падежна функция, в прилагателните имена се изоставя членната форма, въведена от Дринов на -ий, и се приемат формите на -ият, -ия (добрият, добрия вместо добрий), запазва се буквата $m^{13}$.

Правописните идеи на Иван Вазов не са възприети в онзи момент, но са приети от следващия министьр на просветата Тодор Иванчев, който през 1899 г. издава упьтването с някои поправки. Този правопис получава по-широка гласност и е наречен ДриновскоИванчевски, поради многото заемки от правописа на Марин Дринов. Сред тях може да се споменат: запазването на етимологичното място на буквата $\mathscr{B}$, запазването в корените на думите на буквата $ж$, като разграничението между ж и $b$ става на етимологическа основа (мкка, но мъх), употребата на букви $b$ и $b$ на края на думите без звукова стойност, при прилагателните имена в м. р. ед. ч. се възприема, съобразно с положението в живия език, пълен или кратък член -ият, -ия, а не -ий; отглаголните съществителни от народния език се пишат с -не, а не с -нье. Този правопис става задължителен за всички училища в страната.

Дриновско-Иванчевският правопис се съобразява с налагащите се тенденции като употребата на $a$, я вместо ж и $九$ в глаголните окончания. Против този Дриновско-Иванчевски правопис се обявява кръгът „Мисъл“, а след 1910 г. съчиненията на Пенчо Славейков се печатат без $\mathfrak{b}^{14}$. Правописът остава действащ до 1921 г. Възстановен е с някои поправки през 1923 г. и е отменен през 1945 г. с деветосептемврийския правопис. 
След Първата световна война министърьт на просветата Стоян Омарчевски назначава комисия, в която участват Беньо Цонев, Александър Теодоров-Балан, Ст. Младенов и др. Комисията вижда сгоден момент да се въведе ред в „правописния хаос“ по определението на Александър Балабанов (Балабанов 1921) и излиза с предложение да се опрости Дриновско-Иванчевския правопис чрез отстраняване на някои трудни за усвояване положения и правила. Въз основа на препоръките на комисията през 1921 г. излиза „УПътване за общ правопис на българския книжовен език“, което става известно като Омарчевски правопис ${ }^{15}$.

През 1923 г. е назначена поредната правописна комисия, начело на която застава проф. Любомир Милетич. Комисията изготвя проект за правопис, подобен на Дриновския - възстановява се ятовата гласна в корени на думи и техни производни, в които има двойно произношение, тоест редуване на я и $е$ (брБг, прибрБжен; голБм, голБми, голБмя се; грБх, грБша; дБл, дБля и пр.). Според проекта думи, в чиито корени и техни производни не се среща книжовен изговор $я$, а само $e$, се пишат с $e$, а не с $\vec{b}$, както е било по официалния правопис до 1921 г. (беда, бедствие, бедя; вреда, вреден, вредя; реч, речник, река; стрела и пр.). Възстановява се $b$ в края на думите и на етимологичното му място в думите (мъхъ, дъно), а също и при членуване (градъ - градътъ, човекъ - човекътъ). Предлага се възстановяване на $b$ в края на думите, както и като знак за мекост в думите и при членуване (Кольо, Цоньо, актьоръ, синьо; конь - коньтъ, учитель - учительтъ). Буквата ж остава да се употребява на етимологичното си място (джб, ржка, вжтре, вжже, тжга и пр.). Синтактичното правило за употреба на пълния и краткия член в м. р. ед. ч. (столът се обърна, но подай ми стола, седни на стола) е единствената главна разлика с правописа на Дринов ${ }^{16}$.

Разликата между т.нар. правопис на Александър Цанков (Цанков правопис) от 1923 г. и правописа на Тодор Иванчов от 1899 г. е само при употребата на ятовата гласна, която в правописа на Иванчов се употребява винаги на етимологичното си място, а в правописа на Цанков е ограничена в случаи, където има редуване на изговор я и $e$.

С въвеждането на правописа на Цанков правописните разногласия не са прекратени. Левият печат продължава да си служи с правописа на Омарчевски. За да пресече тази практика, Ал. Цанков утвърждава със закон своя правопис през 1928 г. Част от езиковедите като Александър Теодоров-Балан и Беньо Цонев водят борба за прилагане на т.нар. академичен правопис, препоръчан през 1922 г. от Историко-филоложкия клон на БАН, но отхвърлен от общото събрание на Академията поради отрицателното отношение на представителите на другите науки. „Академичният“ правопис заменя $\overparen{b}$ с $Я$ и $E$, ж с $b$ и изхвърля еровете в края на думите. През 1924 г. Историко-филоложкият клон на БАН защитава запазването на краесловните ерове.

През 1936 г. министьрьт на просветата Н. П. Николаев назначава петчленна комисия (Ст. Младенов, Ст. Романски, Й. Йовков, Т. п. Върбанов и Ст. п. Василев), на която е възложено да внесе необходимите разяснения в правописа, като същевременно поправи допуснатите в него неточности и отстрани всички неустановености. Малко по-късно назначава друга комисия с разширен състав - 45-членна, която да разгледа постигнатите резултати от първата такава, но поради появилите се разногласия между членовете на комисията отново няма конкретни резултати ${ }^{17}$.

След 1944 г. отношението към правописа придобива още по-ясни политически измерения. Някои правописни правила са възприемани като проява на езиков елитизъм и отчуждение на интелигенцията от масите. Правителството на Отечествения фронт назначава комисия от езиковеди и писатели, която да разгледа възможностите за опростяване на българския правопис. Въпреки силната съпротива на български общественици и писатели, включително и членове на комисията като Елин Пелин, в началото на следващата година комисията внася в Министерския съвет предложение за реформа на българския правопис, което на 27 февруари 1945 г. е публикувано в Държавен вестник като наредба-закон.

От създаването на Дриновския правопис през 1870 до 1944 г. са направени осем опита за установяване на правописни норми. Платформата на тези опити е предимно сп. „Български преглед“. Дриновският правопис е предпочитан заради научните си и логични основи. Също така той е база за останалите правописи, чиито създатели са Иван Вазов, Тодор Иванчов и Любомир Милетич. Дриновският правопис остава най-известният и най-често употребяваният за почти век, за разлика от останалите проекти. 
${ }^{1}$ Георгиева Е. Марин Дринов и изграждането на новобългарския книжовен език // Съвременният български книжовен език (Основни развойни моменти и видни строители). София: Държавно издателство „Народна просвета“, 1983. С. 128 .

2 Андрейчин Л. Из историята на нашето езиково строителство. София, 1986. URL: http:// macedonia.kroraina.com/la/index.html (посетен на 03.09.2017 г.).

${ }^{3}$ Георгиева Е. Марин Дринов и изграждането на новобългарския книжовен език // Съвременният български книжовен език (Основни развойни моменти и видни строители). София: Държавно издателство „Народна просвета“, 1983. С. 128.

${ }_{4}$ Андрейчин Л. Из историята на нашето езиково строителство. София, 1986. URL: http:// macedonia.kroraina.com/la/index.html (посетен на 03.09.2017 г.).

${ }^{5}$ Георгиева E. Марин Дринов и изграждането на новобългарския книжовен език // Съвременният български книжовен език (Основни развойни моменти и видни строители). София: Държавно издателство „Народна просвета“, 1983. С. 128.

${ }^{6}$ Пак там. С. 129

${ }^{7}$ Станков В. Строители и ревнители на родния език. София: Дьржавно издателсво „Наука и изкуство“, 1982. С. 260

${ }^{8}$ Андрейчин Л. Из историята на нашето езиково строителство. София, 1986. URL: http:// macedonia.kroraina.com/la/index.html (посетен на 03.09.2017 г.).

${ }^{9}$ Пак там.

10 Русинов Р. История на българския правопис. София: Издателство „Наука и изкуство“, 1985. C. 57-58.

${ }^{11}$ Пак там. С. 72.

12 Пак там. С. 76.

${ }^{13}$ Калканджиев В., Калканджиева Д. Българският университет и наука та. Т. 1: Висшето училище в София. София, 2014. С. 187.

${ }^{14}$ Русинов Р. История на българския правопис. С. 84.

${ }^{15}$ Пак там. С. 91.

16 Андрейчин Л. Из историята на нашето езиково строителство. София, 1986. URL: http:// macedonia.kroraina.com/la/index.html (посетен на 03.09.2017 г.).

${ }^{17}$ Русинов Р. История на българския правопис. С. 114. 